\title{
EFEKTIVITAS METODE SQ3R PADA MATA PELAJARAN BAHASA INDONESIA DI MI FALAHIYYAH SAMBUNG KOTA SEMARANG 2017
}

\author{
Lailatul Farohah \\ MI Futuhiyyah Mranggen \\ lailayunixs29@gmail.com
}

\begin{abstract}
Abstrak
Kegiatan belajar mengajar tidak lepas dari tujuannya yaitu kemampuan pemahaman dan merupakan salah satu hal yang paling pokok dalam pembelajaran. Kemampuan pemahaman itu sangat perlu dan penting sehingga peneliti berusaha meneliti bagaimana implementasi metode SQ3R pada mata pelajaran bahasa Indonesia. Rencana yang digunakan dalam penelitian ini yaitu: hasil belajar siswa, yang diperoleh melalui tes; aktivitas belajar siswa, yang diperoleh melalui observasi; kemampuan pemahaman membaca siswa yang diperoleh berdasarkan angket. Hasil penelitian ini menghasilkan kemampuan pemahaman belajar siswa, yang diperoleh dari hasil belajar siswa yang mencapai ketuntasan klasikal, adanya kemampuan pemahaman terhadap kegiatan pembelajaran sehingga dapat diperoleh hasil belajar yang maksimal, nilai ratarata hasil belajar siswa yang lebih baik.
\end{abstract}

Kata kunci : Efektifitas, Metode SQ3R, Kemampuan Pemahaman

\begin{abstract}
The aim of teaching learning process is raises understanding ability as one of essential ability in learning. The understanding ability is needed and important so the writer try to conduct a research about the implementation of SQ3R method on Bahasa Indonesia Lesson. Planning which are used in this reseach are : result of students' learning, obtained by test; students' learning activity, obtained by observation; ability of students' reading comprehension, obtained by questionnaires. The result of this study produce the ability of students' learning understanding, obtained by the result of students' learning which reach classical completeness, there are understanding ability on learning activity so can be obtained maximum learning result, better students average score.
\end{abstract}

Keywords: effectivity, SQ3R method, understanding ability 


\section{A. PENDAHULUAN}

Dewasa ini telah terjadi pergeseran pola sistem mengajar yaitu dari guru yang mendominasi kelas menjadi guru sebagai fasilitator dalam proses pembelajaran. Guru hanya menggunakan buku pegangan yang ada dan hanya mengandalkan metode ceramah, tanpa menggunakan media yang sesuai dengan materi. Akibatnya keaktifan, partisipasi, dan hasil belajar siswa menjadi rendah.

Kemajuan suatu masyarakat dapat diukur dari kebiasaan membaca dan menulisnya. Hal ini sudah diketahui sejak lama. Jepang tidak hanya terkenal oleh produk teknologi tingginya, seperti industri mobil, elektronika, dan industri berat, bahkan juga terkenal dengan cerita komik, novel dan film kartun. Semua itu diawali oleh tradisi membaca, yang kemudian dilanjutkan dengan menulis. ${ }^{1}$ Kemampuan membaca yang tinggi menjadi syarat bagi setiap orang untuk maju. Semua orang dituntut mempunyai daya baca yang tinggi.

Daya baca yang tinggi diperoleh dari pengetahuan tentang cara membaca yang baik dan pengembangan yang terus menerus. Membaca bukanlah sekedar kemampuan mengenal kata atau kalimat. Ada teori khusus yang sejak lama dikembangkan oleh para ahli untuk meningkatkan daya baca. Intinya, kemampuan membaca (daya baca) itu dapat ditingkatkan. Pengembangan kemampuan membaca mempunyai landasan ilmiah yang kuat. ${ }^{2}$ Kemampuan membaca yang tinggi menjadi syarat bagi setiap orang untuk maju. Semua orang dituntut mempunyai daya baca yang tinggi. Daya baca yang tinggi diperoleh dari pengetahuan tentang cara membaca yang baik dan pengembangan yang terus menerus.

${ }^{1}$ Nurhadi, Strategi Meningkatkan Daya Baca, Malang: Bumi Aksara. 2015. hlm. 11.

${ }^{2}$ Nurhadi, Strategi Meningkatkan Daya Baca, hlm. 1. 
Membaca bukanlah sekedar kemampuan mengenal kata atau kalimat. Ada teori khusus yang sejak lama dikembangkan oleh para ahli untuk meningkatkan daya baca. Intinya, kemampuan membaca (daya baca) itu dapat ditingkatkan. Pengembangan kemampuan membaca mempunyai landasan ilmiah yang kuat. ${ }^{3}$

Berdasarkan uraian di atas, maka disimpulkan bahwa pentingnya menggunakan metode $\mathrm{SQ}^{4} \mathrm{R}^{4}$ untuk meningkatkan kemampuan membaca peserta didik dan membiasakan peserta didik untuk membaca. Karena dengan membaca akan membuka jendela dunia. Sebagaimana terdapat dalam al-qur'an surat al-mujadilah ayat 11:

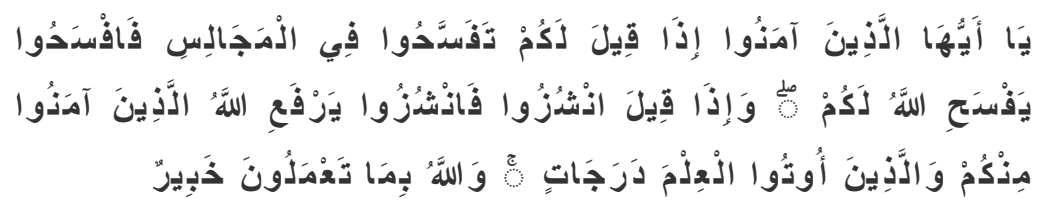

Artinya: Wahai orang-orang yang beriman! Apabila dikatakan kepadamu, "Berilah kelapangan dalam majelis-majelis,"maka lapangkanlah, niscaya Allah akan memberi kelapangan untukmu. Dan apabila dikatakan,"Berdirilah kamu," maka berdirilah, niscaya Allah akan mengangkat (derajat) orang-orang yang beriman di antaramu dan orang-orang yang beriman diantaramu dan orang-orang yang diberi ilmu beberapa derajat. Dan Allah meneliti apa yang kamu kerjakan. ${ }^{5}$

Berdasarkan uraian di atas, maka peneliti tertarik untuk membuat penelitian mengenai efektifitas metode SQ3R pada mata pelajaran bahasa Indonesia di MI Falahiyyah Sambung kota Semarang.

3 Nurhadi, Strategi Meningkatkan Daya Baca, hlm. 1.

4 Metode SQ3R yakni suatu metode studi yang meliputi lima tahap kegiatan membaca yang terdiri dari: (1) survey (meneliti), (2) question (mengajukan pertanyaan), (3) read (membaca), (4) recite (menceritakan kembali),dan (5) review (mengulang kembali). Penerapan Metode SQ3R untuk Meningkatkan ... dalam setiaekawatimakalah.blogspot.com/2012/12/penerapanmetode-sq3r-untuk.html

${ }^{5}$ Departemen agama RI.Al-Qur'an Dan Terjemahnya. 2002. Jakarta.hlm. 


\section{B. LANDASAN TEORI}

Kemampuan (ability) adalah kecakapan atau potensi seseorang individu untuk menguasai keahlian dalam melakukan atau mengerjakan beragam tugas dalam suatu pekerjaan atau suatu penilaian atas tindakan seseorang. ${ }^{6}$ Ada 3 jenis kemampuan dasar yang harus dimiliki untuk mendukung seseorang dalam melaksanakan pekerjaan atau tugas, sehingga tercapai hasil yang maksimal, yaitu:

a. Kemampuan teknis (Technical Skill)

Adalah pengetahuan dan penguasaan kegiatan yang bersangkutan dengan cara proses dan prosedur yang menyangkut pekerjaan dan alat-alat kerja.

b. Kemampuan bersifat manusiawi (Human Skill)

Adalah kemampuan untuk bekerja dalam kelompok suasana di mana organisasi merasa aman dan bebas untuk menyampaikan masalah.

c. Kemampuan konseptual (Conceptual Skill)

Adalah kemampuan untuk melihat gambar kasar untuk mengenali adanya unsur penting dalam situasi memahami di antara unsurunsur itu. ${ }^{7}$

Menurut Kamus Umum Bahasa Indonesia membaca adalah "melihat serta memahami isi dari apa yang tertulis".8 Membaca ialah proses memahami pesan tertulis dengan menggunakan bahasa

${ }^{6}$ Diaryan. Pengertian dan jenis bakat, minat dan kemampuan. 2014. Diakses melalui http:diaryan2.blogspot.com, pada Rabu 23/11/2016. Pukul 20:16 WIB

${ }^{7}$ Moenir, A.S. Manajemen Pelayanan Umum di Indonesia. 2008. Jakarta: Bumi Aksara, hlm.15.

8 Tim Reality. Kamus Terbaru Bahasa Indonesia. 2008. Surabaya: Reality Publisher. hlm. 79 
tertentu yang disampaikan oleh penulis kepada pembacanya. ${ }^{9}$ Allah swt telah memerintahkan umat-Nya untuk membaca, hal ini dibuktikan dengan diturunkannya surah Al-alaq 1-5 sebagai wahyu pertama yang turun kepada nabi Muhammad saw. Pada saat itu nabi sedang giat-giatnya bertahannuts (ibadah tertentu) di gua hira untuk menghilangkan keresahan hatinya menyaksikan tradisi kaumnya yang jahiliyyah dan jauh dari nilai-nilai kebenaran. Maka dari itu tepat pada bulan ramadhan turunlah surat al-alaq 1-5.10

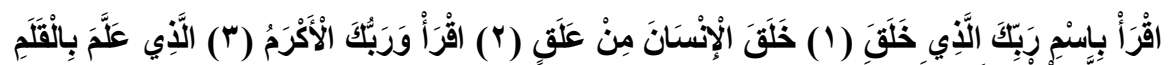

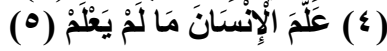

Artinya : Bacalah dengan (menyebut) Nama Rabb-mu yang menciptakan. Dia telah menciptakan manusia dengan segumpal darah. Bacalah, dan Rabb-mulah Yang Paling Pemurah. Yang mengajar (manusia) dengan perantaraan kalam. Dia mengajarkan kepada manusia apa yang tidak diketahuinya.

1. Pengertian SQ3R

Metode SQ3R merupakan suatu prosedur belajar yang sistematik dan bersifat praktik. Metode SQ3R merupakan suatu metode membaca yang sangat baik untuk kepentingan membaca secara intensif dan rasional.11 SQ3R memberi kemungkinan kepada para siswa untuk belajar secara sistematis, efektif, dan efisien dalam menghadapi berbagai materi ajar. Strategi ini lebih efisien digunakan untuk belajar karena siswa dapat berulang-ulang mempelajari materi ajar dari tahap meneliti bacaan atau materi ajar (Survey), bertanya (Question), membaca atau mempelajari (Read),

9 Ahmad, Alek. Bahasa Indonesia Untuk Perguruan Tinggi. Jakarta: Erlangga. 2016. hlm.43.

${ }^{10}$ Saiful hadi. Juz' Amma 'keagungan surat-surat pendek Al-Qur'an dalam Juz' Amma”. Jakarta: Iniperbesa. 2016. hlm.96

${ }^{11}$ Ludin Bastra, SQ3R. Diakses melalui http://ludinbastra.blogspot.co.id, pada rabu 06/04/16, pukul 20:20 WIB. 
menceritakan atau menuliskan kembali (Recite), dan meninjau ulang (Review).12

Hanafiah memberikan penjelasan tentang Effective Study, melalui kegiatan membaca dengan metode SQ3R, yaitu:

a. Survey, yaitu menyelidiki terlebih dahulu untuk mendapat gambaran selintas mengenai isi/pokok yang akan dipelajari.

b. Question, yaitu mengajukan pertanyaan dari ide pokok atau isi buku yang dibaca secara selintas.

c. Read, yaitu membaca secara aktif untuk memberikan jawaban terhadap pertanyaan yang dibuat.

d. Recite, yaitu mengucapkan kembali atas jawaban yang diberikan terhadap pertanyaan dengan tidak melihat buku/menengok terhadap catatan kecil yang menjadi garis besar.

e. Review, yaitu mengulang apa yang dibacanya dengan memeriksa kertas catatannya. ${ }^{13}$

Peserta didik akan bosan dan jenuh serta kurang menfokuskan perhatiannya terhadap pelajaran yang monoton. Maka dari itu guru harus kreatif dan inovatif dalam memilih dan menggunakan metode dalam pembelajaran. Hindari penggunaan metode yang metode yang konvensional seperti ceramah, peserta didik akan lebih senang dan tertarik ketika guru melibatkan siswa dalam belajar. Siswa terlibat langsung menemukan hal-hal yang baru, serta dapat mengaplikasikannya dengan apa yang dialaminya dalam kehidupan sehari-hari.

Sebagaimana kita ketahui pemikiran anak-anak sekolah dasar merupakan tahap pemikiran konkret-operasional (concret operational thought) dimana dalam masa ini aktivitas mental anak

${ }^{12}$ Pujawan, I. G. N. Penerapan Model Pembelajaran Kooperatif dengan Metode SQ3R dalam Meningkatkan Aktivitas dan Prestasi Belajar Matematika Siswa SMP. 2005. Jurnal Pendidikan dan Pengajaran IKIP Negeri Singaraja. No. 3:343-358.

${ }^{13}$ Hanafiah, N., dkk., Konsep Strategi Pembelajaran, Bandung: PT Refika Aditama, hlm. 59. 
terfokus pada objek-objek yang nyata. Maka sesuai dengan teori tersebut seorang siswa, terutama siswa MI akan lebih senang dengan hal-hal yang konkret. Membiasakan siswa menemukan halhal yang baru akan menimbulkan keseimbangan dalam belajar, belajar dalam dunia pendidikan/sekolah dan belajar dari lingkungan sekitar/tempat tinggal. Tugas guru adalah mampu dan sanggup menjalankan peranannya sebagai guru, pembimbing, dan sebagai motivator bagi peserta didiknya.

Dari uraian diatas, metode $S Q 3 R$ merupakan salah satu metode yang mana di dalamnya penggunaannya dapat merangsang peserta didi untuk dapat memahami mengenai hal-hal yang kongkret, yang mana dapat dihubungkan dengan kegiatan seharihari. jadi, dengan metode $S Q 3 R$ siswa dapat menemukan hal-hal yang baru dan melatih untuk berfikir kritis terhadap apa yang sedang ia pelajari dan apa yang sedang Ia alami.

Kecepatan membaca seseorang harus seiring dengan kecepatan memahami bahan bacaan yang telah dibaca. Dan pernyataan terakhir menyinggung keterampilan membaca yang menyebutkan bahwa kemampuan membaca merupakan keterampilan memilih isi bacaan yang harus dibaca sesuai dengan tujuan, yang ada relevansinya dengan pembaca tanpa membuangbuang waktu untuk menekuni bagian-bagian lain yang tidak diperlukan.

Sehingga dapat disimpulkan bahwa dalam membaca diperlukan konsentrasi yang lebih ketika membaca dan juga diperlukan perpaduan kemampuan motorik dengan kemampuan kognitif serta diperlukan waktu yang relatif singkat guna 
memperoleh informasi yang ada dalam bacaan baik yang tersirat maupun tersurat.

Hal-hal tersebut di atas merupakan sejumlah pengertian yang pada akhirnya merujuk kepada pengertian membaca cepat. Kemampuan membaca cepat seseorang pada dasarnya memiliki hubungan terhadap kemampuan mengkritisi sebuah tulisan. Namun, perlu kita ketahui bahwa kemampuan mengkritisi sebuah tulisan tidak lepas dari latar belakang pendidikan maupun pengalaman seseorang dan ini berarti hal terkait membaca cepat atau kritis berkaitan dengan pendidikan, khususnya pendidikan bahasa. Dalam pengajarannya, selain memerlukan tulisan sebagai media dan bahan ajar tentunya juga memerlukan teknik atau metode yang tepat dalam pelaksanaannya.

2. Manfaat Metode SQ3R

Ada beberapa manfaat yang bisa dipetik dari penggunaan metode SQ3R. Dengan metode ini siswa akan menjadi pembaca aktif dan terarah langsung pada pokok bacaan. Mintowati14 dalam bukunya menjelaskan manfaat metode SQ3R sebagai berikut:

a. Survey terhadap bacaan akan memberi kemungkinan pada pembaca untuk menentukan apakah bacaan tersebut sesuai dengan keperluannya atau tidak. Jika memang bacaan itu diperlukan, tentu pembaca akan meneruskan kegiatan bacanya. Jika tidak, pembaca akan mencari bahan lain yang sesuai dengan kebutuhan atau keinginannya.

b. Metode SQ3R memberi kesempatan kepada para pembaca untuk berlaku fleksibel. Artinya pengaturan kecepatan membaca untuk setiap bagian bahan bacaan tidaklah harus sama. Pembaca akan

${ }^{14}$ Mintowati, Panduan Penulisan Bahan Ajar, Jakarta: Dekdikbud, 2003, hlm. 23 . 
memperlambat tempo bacaannya jika menemukan hal-hal yang reletif baru baginya, hal-hal yang memerlukan pemikiran untuk memahaminya, atau mungkin bagian-bagian bacaan yang berisi informasi yang diperlukan pembacan. Sebaliknya, pembaca akan menaikkan tempo kecepatan bacanya, jika bagian-bagian bacaan itu dipandang kurang relevan dengan kebutuhannya atau mungkin bagian tersebut sudah dikenalinya.

c. Metode SQ3R membekali pembaca untuk belajar secara sistematis.

d. Penerapan metode SQ3R dalam pembelajaran akan menghasilkan pemahaman yang komprehensif, bukan ingatan. Pemahaman yang komprehensif akan bertahan lebih lama tersimpan di dalam otak, daripada sekedar mengingat fakta.

e. Metode SQ3R dapat meningkatkan pencapaian hasil belajar dengan efektif dan efisien apabila dibandingkan dengan belajar tanpa metode.

Dari uraian di atas menunjukkan bahwa metode SQ3R cocok digunakan untuk menjembatani siswa meningkatkan keterampilan dalam membaca. Metode ini memungkinkan para siswa untuk belajar membaca pemahaman secara sistematis dari awal sampai akhir kegiatan membaca.

3. Langkah-langkah Metode SQ3R

Kegiatan membaca melalui metode SQ3R terdiri atas lima langkah yakni survey, question, read, recite dan review. Soedarso menjelaskan langkah-langkah kegiatan membaca dengan penerapan metode SQ3R secara lengkap sebagai berikut ini: ${ }^{15}$

a. Langkah 1: S-Survey

${ }^{15}$ Soedarso, Speed Reading Sistem Membaca Cepat dan Efektif, Jakarta: Gramedia Pustaka Utama, 2010, hlm. 59-64. 
Survey atau prabaca adalah teknik untuk mengenal bahan sebelum membaca secara lengkap untuk mengenal organisasi dan ikhtisar umum. Kegiatannya bisa melihat-lihat judul, subjudul dan sebagainya.

b. Langkah 2: Q-Question

Kegiatan yang dilakukan adalah mengajukan pertanyaan tentang isi bacaan, misalnya dengan mengubah judul atau subjudul menjadi kalimat tanya, bisa menggunakan kata siapa, apa, kapan, dimana, mengapa, bagaimana.

c. Langkah 3: R-Read

Kegiatan yang dilakukan adalah membaca keseluruhan bahan bacaan. Baca bagian demi bagian sambil mencari jawaban atas pertanyaan yang telah tersusun.

d. Langkah 4: R-Recite

Setiap selesai membaca suatu subjudul, berhentilah sejenak untuk menjawab pertanyaan atau menyebutkan hal-hal penting dari bacaan tersebut. Bila perlu, buatlah catatan seperlunya. Bila belum paham, ulangi membaca bagian tersebut sekali lagi.

e. Langkah 5: R-Review

Setelah membaca seluruh bacaan, ulangi untuk menelusuri kembali judul, subjudul dan bagian-bagian penting lainnya. Langkah ini berguna untuk membantu daya ingat, memperjelas pemahaman dan juga untuk mendapatkan hal penting yang terlewatkan.

Dengan mengetahui lima langkah kegiatan membaca di atas yakni survey, question, read, recite dan review mampu memberikan pemahaman yang baik bagi peserta didik. sebab pembelajaran membaca merupakan suatu proses pembelajaran yang menitikberatkan pada penguasaan teks atau pemahaman teks yang 
dibaca serta kemampuan siswa dalam menjawab beberapa pertanyaan yang diberikan oleh guru.

\section{METODE PENELITIAN}

Pengumpulan data dalam penelitian ini adalah hasil belajar yang diperoleh dari tes tertulis, aktivitas belajar siswa yang diperoleh melalui observasi, kemampuan pemahaman membaca siswa yang diperoleh berdasarkan angket. Kegiatan belajar mengajar dikatakan berhasil apabila proses pembelajaran itu berjalan dengan baik dan secara klasikal diperoleh hasil belajar yang baik. Adakah perubahan /perbedaan antara sebelum dan sesudah menggunakan metode SQ3R pada mata pelajaran bahasa Indonesia, adakah perbedaan hasil belajar dengan menggunakan ekspositori learning.

Penelitian ini termasuk penelitian eksperimen. Pada penelitian ini peneliti menggunakan populasi yaitu seluruh siswa kelas V MI Falahiyyah Sambung kota Semarang tahun ajaran 2017 yang terdiri dari laki-laki dan perempuan. Sampel dalam penelitian ini diambil dari 1 kelas kontrol dan 1 kelas eksperimen. Pada penelitian ini yang menjadi kelas kontrol adalah kelas $\mathrm{V}$ putri, sedangkan yang menjadi kelas eksperimen adalah kelas V putra MI Falahiyyah Sambung.

\section{HASIL DAN PEMBAHASAN}

Kegiatan belajar mengajar dengan menggunakan metode SQ3R yang mana diharapkan agar siswa dapat menemukan hal-hal yang baru dengan penekanan pada siswa supaya aktif dan berpartisipasi dalam pembelajaran baik secara individu maupun kelompok. Dari hasil observasi saat kegiatan pembelajaran berlangsung, diperoleh penemuan pertama sampai akhir telah terjadi peningkatan aktivitas belajar siswa baik secara individu maupun kelompok. Hal ini dapat 
dibuktikan dari hasil observasi pada pertemuan pertama, keaktifan siswa rata-rata 45,3 dari nilai maksimum 10 , pada pertemuan kedua 73,7 dan pertemuan ketiga 85,4. Hal ini sesuai dengan apa yang telah dipaparkan diatas bahwa metode SQ3R dapat meningkatkan keaktifan siswa untuk mencapai tujuan pembelajaran.

Dari hasil angket siswa dapat diketahui bahwa prosentase terbesar siswa terhadap komponen mengajar adalah aktif dan menyenangkan. Di sisi lain siswa mengharapkan penggunaan metode SQ3R bukan hanya pada materi membaca saja, akan tetapi pada materi-materi lain berikutnya. Siswa lebih tertarik dan mudah dalam memahami materi yang disampaikan oleh guru, hal ini dibuktikan dengan adanya observasi, tes dan hasil belajar. Motivasi belajar siswa yang tinggi sesuai dengan hasil rata-rata nilai yang diperoleh dari angket mencapai nilai 9,5 dari skor nilai maksimal 10. Secara umum dapat disimpulkan bahwa motivasi belajar siswa meningkat tinggi ketika belajar dengan menggunakan metode SQ3R.

Kegiatan belajar siswa meningkat dan menunjukkan motivasi belajar yang tinggi pada saat pembelajaran dengan menggunakan metode SQ3R, karena suasana belajar menjadi menyenangkan, menarik serta perhatian siswa lebih terfokus dan terangsang untuk memikirkan hal-hal yang berhubungan dengan materi yang ia pelajari, siswa dapat aktif dan berperan serta/siswa dapat mengaplikasikan terhadap apa yang telah ia alami.

Persiapan sebelum melaksanakan penelitian, terlebih dahulu peneliti melakukan uji validitas, reliabilitas, tingkat kesukaran dan daya pembeda terhadap soal yang akan diujikan/diteskan. Ada 20 soal yang digunakan dalam tes hasil belajar, dan soal tersebut merupakan soal uraian singkat. Sehingga memudahkan siswa dalam menjawab soal tes hasil belajar yang diujikan. 
Berdasarkan nilai tes hasil belajar siswa diperoleh berdasarkan hasil kelas eksperimen dikatakan tuntas secara klasikal dan individual berdasarkan perhitungan statistik. Perhitungan ini membuktikan bahwa hasil penelitian ini mendukung teori atau penelitian yang telah dilakukan sebelumnya. Kegiatan pembelajaran dengan menggunakan metode SQ3R secara signifikan memiliki dampak yang baik terhadap hasil belajar peserta didik, terutama dalam pemahaman kemampuan.

Metode SQ3R pada mata pelajaran bahasa Indonesia telah dimodifikasi oleh peneliti sehingga memberikan hasil pada kelas eksperimen yaitu pengaruh aktivitas belajar dan motivasi belajar terhadap hasil belajar siswa. Hal ini memberikan gambaran tentang ketertarikan, kegiatan pembelajaran pada saat menggunakan metode SQ3R, maka dari itulah siswa mampu mengeksplorasi permasalahan, mencari sendiri/belajar mandiri dengan menemukan permasalahan dan dapat menyelesaikan permaslahan yang ditemukan. Kemampuan pemecahan masalah yang terlihat paling menonjol pada siswa yaitu ketika siswa berdiskusi bersama, tanya jawab, saling berargumen mengungkapkan apa yang ia pikirkan dan permasalahan yang mereka temukan. Sehingga kegiatan belajar dapat tuntas bahkan melebihi apa yang ditargetkan.

Berdasarkan uji statistik menunjukkan bahwa hasil belajar siswa eksperimen lebih baik dibandingkan dengan kelas kontrol dengan rata-rata 63,5 dan kelas eksperimen 85. Hasil dari penelitian ini mendukung bahwa dengan menggunakan metode SQ3R kegiatan pembelajaran akan lebih menarik dan siswa dapat menemukan permasalahan dan memecahkan permasalahan dengan berdiskusi dengan temannya untuk memecahkan permasalahan yang ditemukan.

Dengan demikian. penelitian menggunakan metode SQ3R pada mata pelajaran bahasa Indonesia materi cerpen efekif. Pembelajaran 
efektif dapat diketahui dari hasil pembelajaran yang memenuhi ketuntasan baik secara invidu maupun klasikal, motivasi dan aktivitas pembelajaran memiliki dampak positif terhadap hasil belajar siswa dan suasana pembelajaran menjadi hidup/semuanya aktif, hasil belajar siswa dengan menggunakan metode SQ3R lebih baik baik dari pada hasil belajar siswa dengan menggunakan ekspositori learning.

\section{E. SIMPULAN}

Kegiatan belajar dengan menggunakan metode SQ3R pada mata pelajaran bahasa Indonesia materi cerpen di MI Falahiyyah efektif, hal ini dapat dilihat dari ketuntasan hasil belajar siswa, tuntas secara individu maupun klasikal, pengaruh aktivitas kegiatan belajar mengajar menjadi sangat menarik dan menyenangkan serta berdampak positif terhadap peningkatan hasil belajar siswa. Hal ini dapat dilihat dari uji banding bahwa ada perbedaan hasil belajar antara kelas eksperimen dan kelas kontrol dengan rata-rata hasil belajar kelas eksperimen lebih baik dari pada kelas kontrol.

Berdasarkan hasil penelitian yang telah dilakukan oleh peneliti, maka dapat diberikan saran sebagai berikut:

1. Kegiatan belajar mengajar materi membaca pemahaman dapat digunakan metode SQ3R sebagai alternatif peningkatan kemampuan membaca pemahaman siswa pada mata pelajaran bahasa Indonesia bahkan juga pada mata pelajaran yang lain dan materi yang lain dengan modifikasi yang tepat. 
2. Perlu diadakan penelitian tindak lanjut untuk mengetahui metode yang tepat dalam kegiatan pembelajaran untuk meningkatkan kemampuan membaca pemahaman. 


\section{DAFTAR PUSTAKA}

Ahmad, Alek, Bahasa Indonesia Untuk Perguruan Tinggi, Jakarta: Erlangga, 2016.

Departemen agama RI., Al-Qur'an Dan Terjemahnya, Jakarta: 2002.

Diaryan. 2014. Pengertian dan jenis bakat, minat dan kemampuan. Diakses melalui http:diaryan2.blogspot.com, pada Rabu 23/11/2016. Pukul 20:16 WIB

Hanafiah, N., dkk., Konsep Strategi Pembelajaran, Bandung: PT Refika Aditama, 2010

Ludin Bastra. SQ3R. Diakses melalui http://ludinbastra.blogspot.co.id, 2016, pada rabu 06/04/16, pukul 20:20 WIB.

Mintowati, Panduan Penulisan Bahan Ajar, Jakarta: Dekdikbud., 2003.

Moenir, A.S., Manajemen Pelayanan Umum di Indonesia, Jakarta: Bumi Aksara, 2008.

Nurhadi, Strategi Meningkatkan Daya Baca, Malang: Bumi Aksara, . 2015.

Pujawan, I. G. N., Penerapan Model Pembelajaran Kooperatif dengan Metode SQ3R dalam Meningkatkan Aktivitas dan Prestasi Belajar Matematika Siswa SMP. 2005, Jurnal Pendidikan dan Pengajaran IKIP Negeri Singaraja, No. 3:343-358, 2005.

Saiful hadi, Juz' Amma 'keagungan surat-surat pendek Al-Qur'an dalam Juz' Amma", Jakarta : Iniperbesa, 2016.

Soedarso, Speed Reading Sistem Membaca Cepat dan Efektif, Jakarta: Gramedia Pustaka Utama, 2010.

Tim Reality, Kamus Terbaru Bahasa Indonesia, Surabaya: Reality Publisher, 2008. 